University of Nebraska - Lincoln

DigitalCommons@University of Nebraska - Lincoln

1991

\title{
Preserved Grasshopper Fauna Of Knife Point Glacier, Fremont County, Wyoming, U.S.A.
}

Jeffrey A. Lockwood

Craig D. Thompson

Larry D. Debrey

Charles M. Love

Richard A Nunamaker

See next page for additional authors

Follow this and additional works at: https://digitalcommons.unl.edu/entomologyother

Part of the Entomology Commons

Lockwood, Jeffrey A.; Thompson, Craig D.; Debrey, Larry D.; Love, Charles M.; Nunamaker, Richard A; and Pfadt, Robert E., "Preserved Grasshopper Fauna Of Knife Point Glacier, Fremont County, Wyoming, U.S.A." (1991). Entomology Papers from Other Sources. 48.

https://digitalcommons.unl.edu/entomologyother/48

This Article is brought to you for free and open access by the Entomology Collections, Miscellaneous at DigitalCommons@University of Nebraska - Lincoln. It has been accepted for inclusion in Entomology Papers from Other Sources by an authorized administrator of DigitalCommons@University of Nebraska - Lincoln. 


\section{Authors}

Jeffrey A. Lockwood, Craig D. Thompson, Larry D. Debrey, Charles M. Love, Richard A Nunamaker, and Robert E. Pfadt 


\title{
PRESERVED GRASSHOPPER FAUNA OF KNIFE POINT GLACIER, FREMONT COUNTY, WYOMING, U.S.A.
}

\author{
Jeffrey A. Lockwood, ${ }^{*}$ Craig D. Thompson, ${ }^{\dagger}$ Larry D. Debrey, ${ }^{*}$ Charles M. Love, ${ }^{\dagger}$ \\ Richard A Nunamaker, ${ }^{\ddagger}$ and Robert E. PfadT*
}

\begin{abstract}
In 1987 and 1988, samples of preserved insects were extracted from the ice of Knife Point Glacier, Fremont County, Wyoming. The glacier lies at an altitude of $3500 \mathrm{~m}$ a.s.l. in the Shoshone National Forest, Wind River Range, and is known to contain preserved insects. Although the glacier has undergone extensive recession in the last $50 \mathrm{yr}$, some insect deposits are still embedded at 20 to $25 \mathrm{~cm}$ below the surface and perhaps much deeper. The frozen deposits appear to consist entirely of grasshoppers. A few, virtually intact, specimens and body parts were in a state of preservation that allowed their identification as Spharagemon campestris McNeill and Melanoplus spretus (Walsh) or M. sanguinipes (F.). The majority of the deposits consisted of partial bodies and isolated parts, including, in order of frequency: mandibles, tibiae, tentoria, femora, wings (primarily tegmina), and cingulae/epiphalli. Deposits from various depths and locations on the glacier were radiocarbon dated at $205 \pm 65$ to $450 \pm 80$ $\mathrm{yr}$ BP. Although access to the glacier is quite difficult, the insects are better preserved than any glacial deposit documented in recent history. Thus, the state of preservation and age of the frozen deposits would suggest that additional, intensive sampling may be valuable in obtaining information on the ecology of grasshoppers prior to European settlement of North America.
\end{abstract}

\section{INTRODUCTION}

The Wind River Range glaciers in northwestern Wyoming contain perhaps the richest deposits of glacially preserved grasshopper (Orthoptera: Acrididae) fauna in the world. According to Meier (1951) and Henderson (1933, 1939), these glaciers, extending along the Continental Divide, include at least five glaciers with frozen grasshoppers. Grasshopper Glacier is the northernmost of the deposits. It is the largest glacier bearing this name (there are four other glaciers named Grasshopper or Hopper glacier) and, as recently as the last $10 \mathrm{yr}$, contained large numbers of specimens (Watson, pers. comm., 1989).

*Department of Plant, Soil and Insect Sciences, University of Wyoming, Laramie, Wyoming 82071, U.S.A.

†Water Quality Laboratory, Western Wyoming Community College, Rock Springs, Wyoming 82902, U.S.A.

${ }^{\ddagger}$ Arthropod-borne Animal Diseases Laboratory, Agricultural Research Service, U.S. Department of Agriculture, Laramie, Wyoming 82071, U.S.A.
Minor Glacier is $3 \mathrm{~km}$ south of Grasshopper Glacier. Meier (1951) reported large amounts of grasshopper remains on the surface of Minor Glacier; a collection of grasshoppers and other insects was unfortunately lost on the way back from the glacier so the species composition is not known. The deposits were apparently relatively recent in origin or were exposed during glacial recession, since the remains were not completely embedded in the ice.

Mammoth Glacier lies about $0.5 \mathrm{~km}$ south of Minor Glacier. Henderson (1933) reported large numbers of rotting grasshoppers on the surface of this glacier. Later observations omit any reference to grasshoppers (Meier, 1951), and it may be presumed that deposits near the surface have been lost.

Henderson (1939) discovered "billions of grasshopper carcasses which stank horribly" on the surface of Fremont Glacier, about $8 \mathrm{~km}$ southwest of Grasshopper Glacier, but later reports (Meier, 1951) made no reference to grass- 
hoppers at this site. On the basis of Henderson's (1939) description, it appears that at least a significant portion of the deposits have been lost.

Knife Point Glacier lies $10 \mathrm{~km}$ southwest of Grasshopper Glacier. Since Henderson (1939) noted the presence of grasshoppers and Meier (1951) did not, we can assume that a portion of the deposits have probably been washed from the glacier during recession in the last $50 \mathrm{yr}$ (Love and Thompson, 1987).

Given the potential value of glacially preserved insect fauna (e.g., the opportunity to deduce the mechanism of extinction of the Rocky Mountain locust, Melanoplus spretus (Walsh) in the late 1800s [Lockwood and DeBrey, 1990; Lockwood et al., 1990a]), it is surprising that no biologist has collected material from any of the Wind River glaciers. However, the lack of collection is undoubtedly due to both the limited information available on these sites and the relative inaccessibility of the glaciers (e.g., Knife Point Glacier is $35 \mathrm{~km}$ from the nearest trailhead). Thus, in 1988 and 1989 we undertook a study to determine the following characteristics of the most accessible of the Wind River glaciers, Knife Point Glacier: the distribution of grasshopper specimens in the glacier, the degree of preservation of the deposits, the date of deposition of the specimens, and the grasshopper species present in the ice. Since there are no preserved samples from the Wind River glaciers, we were also interested in collecting material as a resource for future work.

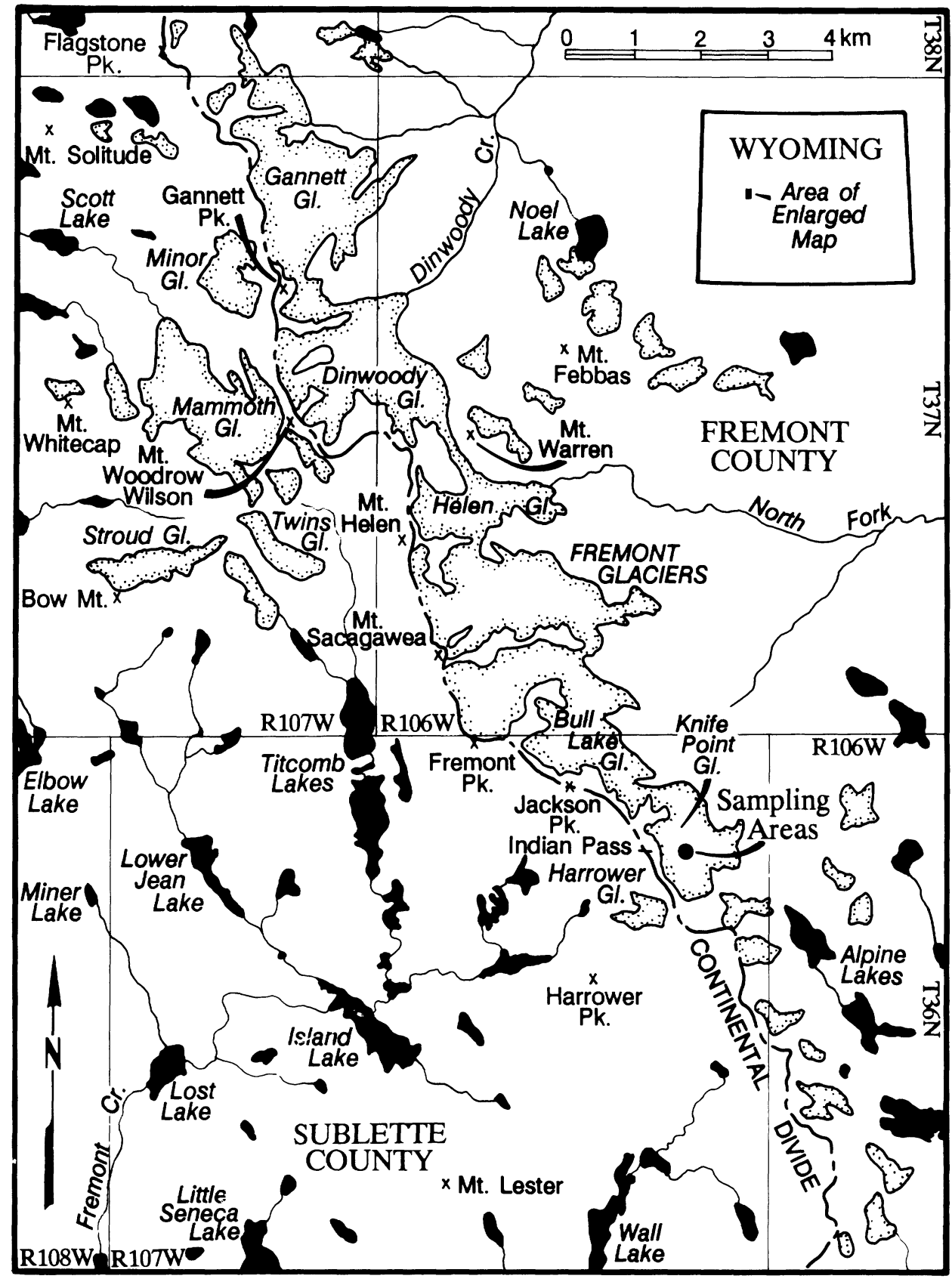

Figure 1. Location of Knife Point Glacier within the Wind River Range of western Wyoming, U.S.A. 


\section{RESEARCH SITE AND METHODS}

Knife Point Glacier is located at $3500 \mathrm{~m}$ a.s.l. in Fremont County, Wyoming, in the Shoshone National Forest, Wind River Range (U.S. Geological Survey, Fremont Peak South Quadrangle, N4300-W10930/7.5, Figures 1 and 2). The glacier lies $35 \mathrm{~km}$ northeast of Pinedale, Wyoming. Observations of insects on the glacier's surface were made in 1985 and 1986. Samples of preserved insects and insect parts within the ice were collected in duplicate from two sites (sites A and B) within a single layer of the ablation zone in August 1987 by C. D. Thompson (Figure 2). These samples were collected $150 \mathrm{~m}$ upslope from the terminus, 20 to $25 \mathrm{~cm}$ below the surface, by chipping with an ice axe or sampling from exposed summer surfaces. Insect samples were collected from five sites in August 1988 by C. M. Love. Two sites (C and D) represented the lowest insect-bearing layers, ca. $100 \mathrm{~m}$ upslope in the ablation zone. Site $E$ represented a composite of material washed from several layers during glacial recession. The richest, insect-bearing layer was collected from two sites ( $F$ and $G$ ), some $100 \mathrm{~m}$ above the terminus in the ablation zone. The principal purpose of the glacial work was the collection of geological and hydrological data, so the insect samples were opportunistically collected in areas of likely deposition and exposure. Given logistical constraints, it was not possible to gather representative samples from a wide variety of locations or to systematically survey the glacier to determine the distribution of preserved insects. However, extensive field notes and observations during the course of geological surveys provided some indication of the likely locations and distribution of the frozen insects.

The condition and state of preservation of the grasshopper deposits were described. Samples were collected using ice axes, chipping tools, and stainless steel forceps; the material was wrapped in aluminum foil and kept frozen by dry ice in a cooler for return to the laboratory, where the deposits were stored at $-5^{\circ} \mathrm{C}$. Because the deposits did not include significant amounts of soft tissues suitable for electrophoretic or related analyses, the material was subsequently thawed, dried in glass under a laboratory hood, and stored in glass at $22^{\circ} \mathrm{C}$. After drying, the material was carefully teased apart in an effort to preserve fragile portions of whole grasshopper bodies intact. The types and abundance of specific grasshopper parts in the material collected from each sampling site were catalogued. A complete analysis of samples less than $10 \mathrm{~g}$ was performed. For samples including over $50 \mathrm{~g}$ of material, the entire sample was censused for whole and partial bodies and large and rare body parts (i.e., tegmina [the leathery forewings], epiphalli [a sclerotized or hardened area in the floor of the male genital chamber], cingulae [a sclerotized or hardened area of the male genitalia], and femora [the third and largest segment of the leg]); smaller, abundant body parts (i.e., tentoria [the endoskeletal support structure of the head], tibiae [the fourth segment of the leg, distal to the femur], and mandibles [the biting, jawlike appendages in the mouth]) were counted from a $10 \mathrm{~g}$ subsample of the material.

Four samples $(0.2$ to $1.0 \mathrm{~g})$ of the material from Knife Point Glacier were submitted to Beta Analytic (Coral Gables, Florida) for radiocarbon dating. The samples were combusted in an enclosed system. The carbon dioxide was collected and purified and then reacted with hydrogen on cobalt catalysts to produce graphite. The accelerator-AMS measurements were made in triplicate at the Eidgenössische Technische Hochschule, Zurich, Switzerland. The dates were adjusted based on the standard correction for ${ }^{13} \mathrm{C} /{ }^{12} \mathrm{C}$. To allow determination of the dating precision and to attain the greatest areal spread we chose a pair of samples from the same insectbearing layer (sites A and B), one sample from the deepest layer (site D), and one sample from the richest layer (site F).

The identity of the grasshopper species collected from the glacier was determined using available taxonomic keys and diagnostic structures (e.g., male genitalia). Once a definitive identification to genus was accomplished,

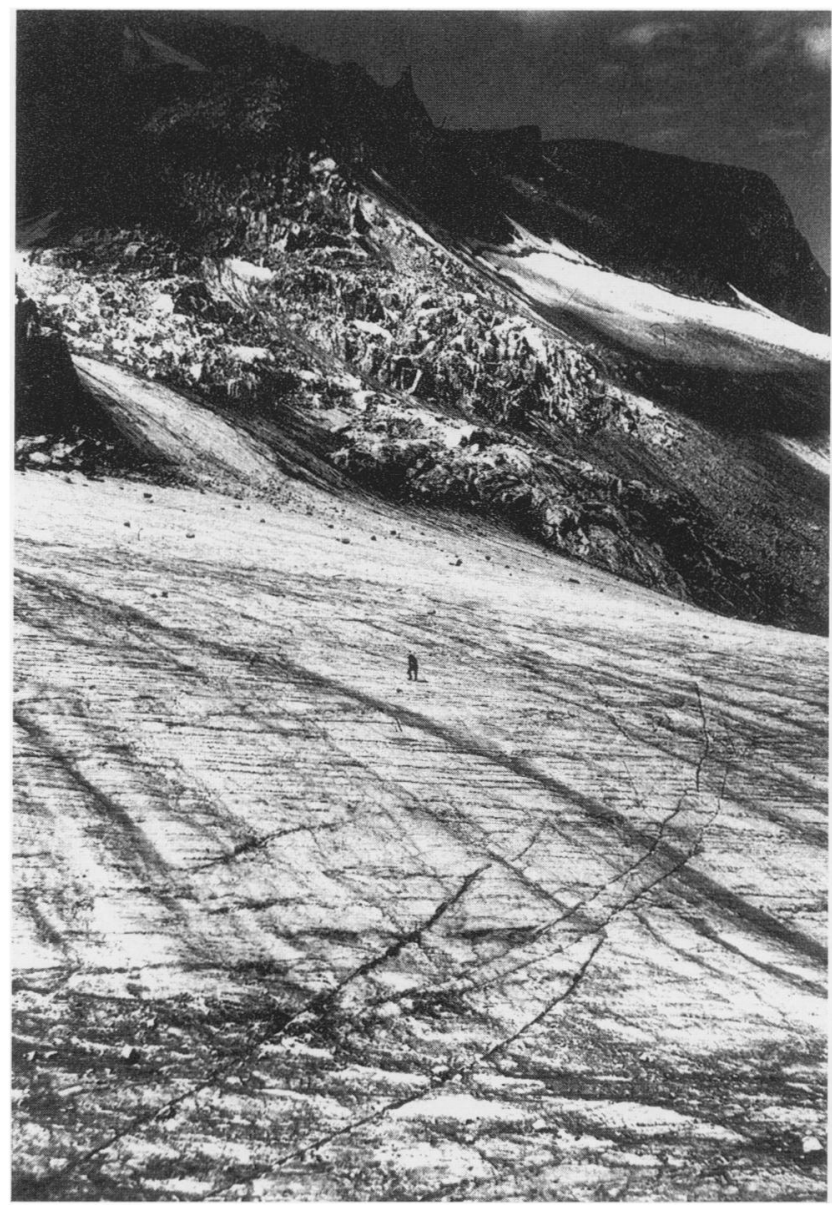

Figure 2. Ablation zone of Knife Point Glacier, Wyoming. Collection sites A and B were within the depicted insect-bearing layers. 
morphometric analyses were attempted for purposes of identifying the remains to species (Lockwood, 1989). Because the sex of the individual body parts could not be determined, it was necessary (but perhaps not entirely accurate [e.g., Popov, 1954]) to assume an equal propor- tion of males and females in the deposits. In many cases, it was necessary to reasonably extrapolate the size of a body part because a portion of the part was missing (e.g., the end of a tegmen).

\section{RESULTS AND DISCUSSION}

The glacially preserved insects of Knife Point Glacier have undergone a considerable degree of dismemberment. We were able to recover 26 partial bodies (representing at least 21 individuals), variously consisting of partial thoraces, tegmina, and abdomens. It would appear that there have been some glacial terminus changes in the last $500 \mathrm{yr}$, including advances during the Little Ice Age (1300 to 1800 A.D. [Grove, 1988]) and dramatic recessions during the last century (Marston et al., 1990). Indeed, the terminus of Knife Point Glacier has receded $228 \mathrm{~m}$ since 1963 (Love and Thompson, 1987). Glacial flow has caused considerable shearing of fragile materials within the ice. Some deposits (sites E-G) are now exposed at the surface of the glacier and appear to be undergoing decomposition. Despite the forces of shearing and decomposition, the deposits are generally in better shape than any other glacially preserved insects studied in recent years (Lockwood et al., 1990a, 1990b). The existence of deeply embedded layers (sites A and B) is particularly encouraging with regard to the potential for further work following more thorough collection.

A number of insect taxa were found on the surface of the glacier, including Lepidoptera (butterflies [family undetermined] and moths [probably Noctuidae]), Hymenoptera (bees [Apoidea] and ants [Formicidae]), Orthoptera (grasshoppers [Acrididae] and crickets [Gryllidae]), and Odonata (dragonflies [family undetermined]). However, the subsurface deposits appear to be restricted to distinct layers and consist solely of grasshoppers. These characteristics are consistent with the deposits having resulted from the fallout of one or more large swarms of migratory grasshoppers, rather than a chronic input of insects from surrounding alpine habitat, as seen on Grasshopper Glacier, Crazy Mountains, Park County, Montana (Lockwood et al., 1990b). Thus, the deposits on Knife Point Glacier resemble those on Grasshopper Glacier, Beartooth Mountains, Park County, Montana (Lockwood et al., 1990a). In order of abundance, the deposits consisted of mandibles, tibia, tentoria, femora, wings, cingulae, epiphalli, and partial bodies (Table 1, Figure 3). Clearly not all sites had the same distribution of these body parts (e.g., no mandibles were found at site A1, and 31 mandibles were found at site B2). However, the general distribution of body parts is very similar to that found on Grasshopper Glacier in the Beartooth Mountains (Lockwood et al., 1990a), although there were relatively more mandibles and fewer femora in Knife Point Glacier. The most heavily sclerotized body parts (mandibles and tibiae) have survived the shearing and decomposition processes. Moreover, it appears that the vast majority of the grasshoppers in the primary, insectbearing layers belong to a single species; the size and color (e.g., red to pink tibiae) of the body parts is uniform, virtually without exception. It had previously been assumed that the assortment of body parts found on the surface of Grasshopper Glacier in the Beartooth Mountains was a result of decomposition (Lockwood et al., 1990a). Based on the composition of deeply buried insectbearing layers on Knife Point Glacier, it appears that the disproportionate number of hardened body parts may

TABLE 1

Distribution of preserved grasshopper body parts collected from Knife Point Glacier, Wyoming

\begin{tabular}{|c|c|c|c|c|c|c|c|}
\hline \multirow[b]{2}{*}{ Site $^{a}$} & \multirow{2}{*}{$\begin{array}{l}\text { Weight } \\
\text { (g, dry) }\end{array}$} & \multicolumn{6}{|c|}{ Number of } \\
\hline & & Mandibles & Tibiae & Tentoria & Femora & Wings & Genitalia $^{\mathrm{b}}$ \\
\hline A1 & 30 & 31 & 2 & 8 & 1 & 5 & 3 \\
\hline A2 & 7 & 0 & 5 & 1 & 0 & 4 & 0 \\
\hline B1 & 18 & 19 & 1 & 0 & 0 & 6 & 1 \\
\hline B2 & 24 & 0 & 19 & 0 & 11 & 0 & 0 \\
\hline C & 3 & 0 & 25 & 0 & 13 & 0 & 1 \\
\hline D & 10 & 37 & 15 & 39 & 9 & 14 & 3 \\
\hline E & $72^{\mathrm{c}}$ & 1010 & 120 & 320 & 80 & 20 & 0 \\
\hline F & $60^{c}$ & 512 & 112 & 136 & 15 & 9 & 2 \\
\hline G & 4 & 0 & 24 & 0 & 11 & 1 & 0 \\
\hline
\end{tabular}

aSee Methods section for site descriptions.

${ }^{b}$ Genitalia include cingulae and epiphalli.

'Numbers of mandibles, tibiae, and tentoriae are extrapolated from a 10-g subsample. 
result from degradation processes that occur even before a deposit becomes exposed to the surface. This may result from anaerobic decomposition of the insect-bearing layer within the ice or from aerobic decomposition as oxygenrich meltwater percolates through the layer.

Radiocarbon dating of samples from sites A and B, within a common layer, revealed ages of $205 \pm 65$ (Beta-32624, ETH-5688) and 330 \pm 65 yr (Beta-32623, ETH-5687), respectively. The overlapping variances on these values suggest an acceptable degree of precision. However, the difference in these dates may imply that this insect-bearing layer is composed of the accumulation of more than a single depositional event. Indeed, two or more layers may be combined during a warm summer, a year of low snowfall, or a combination of meteorological conditions. As expected, the insect layer outcrop on the summer surface, closest to the glacier terminus, contained the oldest insects; sites $\mathrm{D}$ and $\mathrm{F}$ had ages of $410 \pm 65$ (Beta-32625, ETH-5689) and $450 \pm 80 \mathrm{yr}$ (Beta-32626, ETH-5690), respectively. These dates suggest that depositional events may have been relatively frequent and that they occurred prior to European settlement of the western United States. These dates do not agree with a count of approximately 500 supposed summer surface exposures above sites A and B (Figure 2). This large discrepancy is not easily explained, but one possible explanation is that two distinct insect/particulate depositional events (i.e., seasonal wind-blown material) occur each year. We are pursuing several avenues of research that may eventually solve this discrepancy. However, until such time it would seem most judicious to consider the radiocarbon ages as having the greatest accuracy.

Of the 26 partial bodies extracted from the glacial material, only four were in a state of preservation that permitted taxonomic identification. The remaining bodies were crushed and fragmented, often comprised of only a few abdominal segments and portions of the meta- and mesothorax (Figure 3). None of the grasshopper bodies had retained their markings or color. All four of the identifiable bodies were female; two appeared to be Spharagemon campestris and two were Melanoplus sp.

The $S$. campestris females were recognizable from the shape of the intermetasternal space, incisions on the median carina, metazona:prozona ratio, and general body structure (Capinera and Sechrist, 1982; Otte, 1984). We are confident of the genus identification, but because the wing coloration and other diagnostic body markings were obscured, the species designation is less certain. This species may be found at high altitudes (Gilette, 1904), and the source of the specimens from the glacier may have been a local, alpine habitat.

The Melanoplus sp. females' genus was easily determined by the distinct conical spine inserted between the front legs (Capinera and Sechrist, 1985). However, the identification of Melanoplus species depends almost entirely on characteristics of the male genitalia, so the whole bodies could not be identified to species. However, the preserved epiphalli and cingulae were clearly those of $M$. sanguinipes or $M$. spretus (Walsh); they were virtually identical to those recovered from Grasshopper Glacier in the Beartooth Mountains, where the deposits have been tentatively identified as $\boldsymbol{M}$. spretus. Morphometric analyses of diagnostic body parts was equivocal (Table 2). Unfortunately, there were few morphometrically diagnostic body parts preserved, and those of greatest value (i.e., diagnostic for both sexes) did not consistently support either species. Perhaps it should be noted that one entire tegmen measured $23.84 \mathrm{~mm}$, which is within the range of $M$. spretus and well outside the range of $M$. sanguinipes (Lockwood, 1989). Given the age of the deposits, the density of grasshoppers within the deposits, and the biology of rangeland grasshoppers, it appears that Knife Point Glacier may contain a remarkably rich supply of the extinct Rocky Mountain locust (Lockwood and

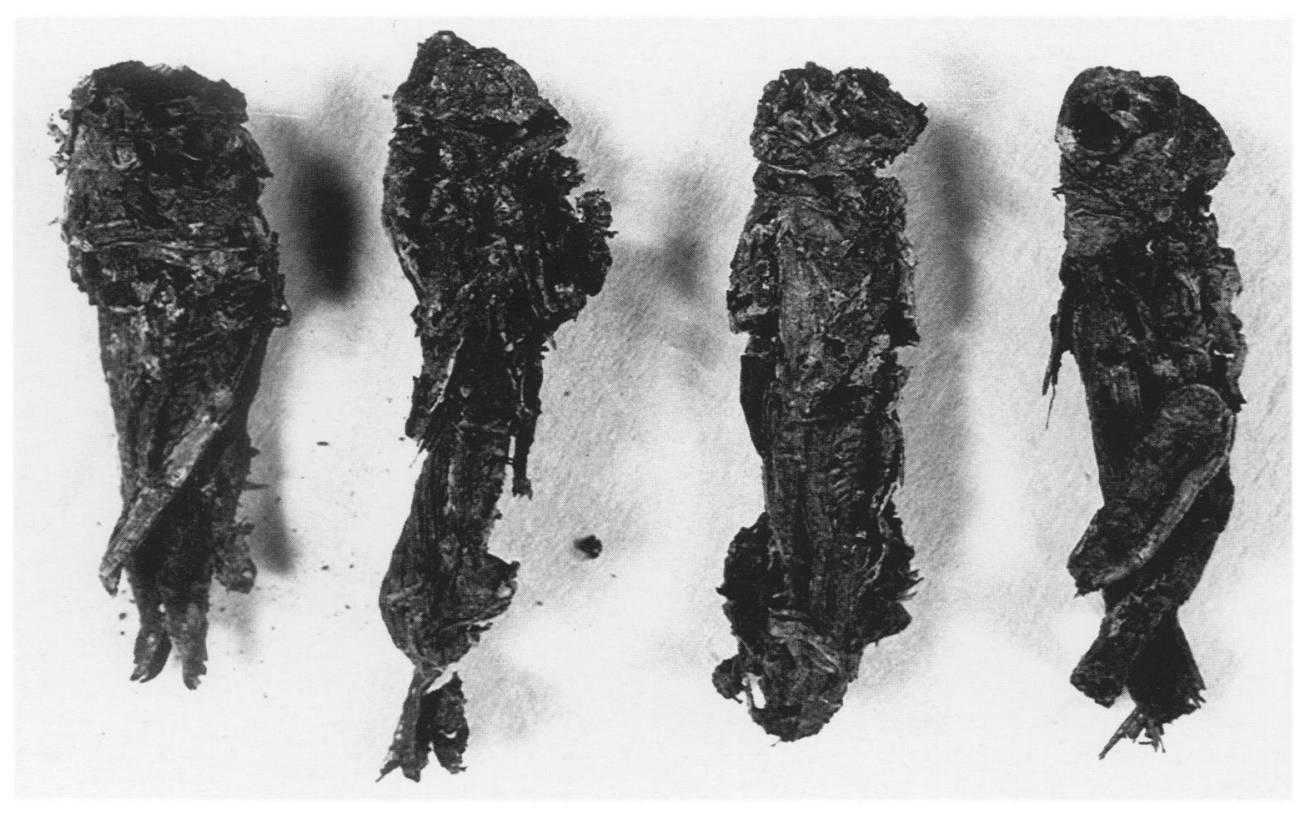

Figure 3. Partial and intact bodies of grasshoppers extracted from the ice of Knife Point Glacier, Wyoming. 
TABLE 2

Morphometric comparisons of diagnostic ${ }^{\mathrm{a}}$ characters in

Melanoplus sanguinipes, M. spretus, and specimens from

Knife Point Glacier, Wyoming

\begin{tabular}{lcrc}
\hline \hline & \multicolumn{3}{c}{ Source } \\
\cline { 2 - 4 } Measurement $^{\mathrm{b}}$ & M. sanguinipes & M. spretus & \multicolumn{1}{c}{ Glacier } \\
\hline Length of sternum & $5.77 \pm 0.71$ & $6.42 \pm 0.53$ & $5.04 \pm 0.00($ (1) \\
Diameter of eye & $1.50 \pm 0.14$ & $1.56 \pm 0.11$ & $1.82 \pm 0.79(2)$ \\
Height of pronotum & $4.16 \pm 0.29$ & $4.41 \pm 0.32$ & $4.07 \pm 0.66(4)$ \\
Length of pronotum & $5.88 \pm 0.38$ & $5.06 \pm 0.28$ & $4.39 \pm 0.11(3)$ \\
Min. width of pronotum & $3.39 \pm 0.28$ & $3.84 \pm 0.27$ & $3.56 \pm 1.75(3)$ \\
Max. width of pronotum & $4.40 \pm 0.43$ & $4.82 \pm 0.34$ & $4.62 \pm 1.15(3)$ \\
Length of metazona & $2.50 \pm 0.24$ & $3.04 \pm 0.22$ & $3.57 \pm 0.21(3)$ \\
Length of tegmen & $19.57 \pm 2.02$ & $25.36 \pm 2.60$ & $22.93 \pm 3.67(28)$ \\
\hline
\end{tabular}

${ }^{a}$ Only the maximum width of the pronotum, length of the metazona, and length of the tegmen are diagnostic for both sexes; the other measurements are diagnostic for one of the sexes.

${ }^{\mathrm{b}}$ Measurements are in $\mathrm{mm}$ and expressed as the mean \pm standard deviation; $\mathrm{N}$ for $M$. sanguinipes is 125 ; $\mathrm{N}$ for $M$. spretus is 124 ; and $\mathrm{N}$ for the glacial specimens is given parenthetically. Measurements of $M$. sanguinipes and $M$. spretus are taken from Lockwood and DeBrey (1989).

DeBrey, 1990). Further collections and investigations will be necessary to clearly establish if this is the case.

Finding fully embedded, relatively well preserved specimens of grasshoppers in the ice of Knife Point Glacier suggests several future directions for research. First, the possibility that intact specimens exist in the other Wind River glaciers now seems highly reasonable. The collection of material from these other sites may provide valuable information on the ecology and biology of grasshoppers on undisturbed ecosystems that no longer exist in North America. Second, the need for more thorough collection of specimens from Knife Point Glacier is imminent. The glaciers in North America are rapidly receding (as much as $\mathbf{9 0 \%}$ in the last $85 \mathrm{yr}$ ) and valuable material has already been lost from at least one important site (Lockwood et al., 1990a). If entirely intact specimens can be collected, we will be able to determine host plant utilization, pathogen loads, and other biological properties of grasshopper species under prehistoric conditions. It has been assumed that outbreaks of rangeland grass- hopper species are a natural phenomenon; data from glacial deposits may allow us to test this assumption. Our approach to management of rangeland grasshoppers should be heavily dependent on whether population explosions of these animals are a recent aberration or an evolutionarily stable process. Finally, the data derived from preserved specimens may provide an answer to the sudden and unexplained extinction of $M$. spretus in the late 1800s. Without accurate knowledge of its biology (e.g., host plant associations, pathogen loads, genetic condition) prior to the $1800 \mathrm{~s}$, the only extinction of an insect pest species remains largely a matter of deductive speculation (Lockwood and DeBrey, 1990).

\section{ACKNOWLEDGMENTS}

We thank M. Sanchez for her invaluable assistance and patience in the separation and sorting of insect parts.

\section{REFERENCES CITED}

Capinera, J. L. and Sechrist, T. S.,1982: Grasshoppers (Acrididae) of Colorado. Colorado State University Experiment Station Bulletin 584S.

Gillette, C. P., 1904: Annotated list of Colorado Orthoptera. Colorado Agricultural Experiment Station Bulletin, 94: 17-67.

Grove, J. M., 1988: The Little Ice Age. New York: Methuen. $498 \mathrm{pp}$.

Henderson, K. A., 1933: The Wind River Range of Wyoming II. Appalachia, 19: 354-375.

Lockwood, J. A. and DeBrey, L. D., 1989: Taxonomic status of the Rocky Mountain Locust: Morphometric comparisons of Melanoplus spretus (Walsh) with solitary and migratory Melanoplus sanguinipes (F.). Canadian Entomologist, 121: 1103-1109.

, 1939: The Wind River Range of Wyoming, supplement. Appalachia, 22: 47-56.

- 1990: A solution for the sudden and unexplained extinction of the Rocky Mountain Grasshopper, Melanoplus spretus (Walsh). Environmental Entomology, 19: 1194-1205.

Lockwood, J. A., Nunamaker, R. A., Pfadt, R. E., and DeBrey, L. D., 1990a: Grasshopper Glacier: Characterization of a vanishing biological resource. American Entomologist, 36: $18-27$. 
Lockwood, J. A., Burne, J. C., DeBrey, L. D., Nunamaker, R. A., and Pfadt, R. E., 1990b: The preserved fauna of Grasshopper Glacier (Crazy Mountains, Montana): Unique insights to acridid biology. Proceedings of the 5th International Conference of the Orthopterists' Society, Valsain, Spain.

Love, C. M. and Thompson, C. D., 1987: Stratigraphy and recent melting of the Wind River Glaciers, Wyoming. Proceedings of the XII International Union for Quaternary Research Congress, Ottawa, Canada.

Marston, R. A., Pochop, L. O., Kerr, G. L., and Varuska, J. L., 1990: Recent trends in glaciers and glacier runoff. Wind River Range, Wyoming. Proceedings of a Symposium of the
American Water Resources Association.

Meier, M. F., 1951: Glaciers of the Gannett Peak-Fremont area, Wyoming. M.S. thesis, State University of Iowa. $159 \mathrm{pp}$. Otte, D., 1984: The North American Grasshoppers. Volume II, Acrididae: Oedipodinae. Cambridge: Harvard University Press.

Popov, G. B., 1954: Notes on the behaviour of swarms of the Desert Locust (Schistocerca gregaria Forskal) in Iran. AntiLocust Bulletin, 14: 1-32.

Watson, W., 1989: Personal communication.

Ms submitted June 1990 